Errors in EFL writing by junior high students in Indonesia

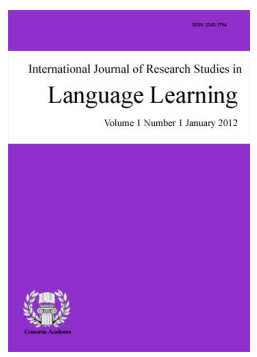

ISSN: $2243-7754$ Online ISSN: 2243-7762

OPEN ACCESS

Mustafa, Faisal

Syiah Kuala University, Indonesia (faisal.mustafa@unsyiah.ac.id)

Kirana, Mulya

Syiah Kuala University, Indonesia (mulya.kirana@gmail.com)

Bahri Ys, Syamsul

Syiah Kuala University, Indonesia (syb_ina@yahoo.com)

Received: 6 November $2015 \quad$ Revised: 29 November $2015 \quad$ Accepted: 2 February 2016

\title{
Abstract
}

Errors made by students in skills such as speaking and writing have been treated as important information to help teachers direct the foci of their teaching. Teachers need to pay attention to the most serious errors before addressing other errors. Hence, this research was aimed at finding the most serious errors produced by students at one of the junior high schools in Indonesia, i.e. State Junior High School No 7 in Banda Aceh. The errors were categorized into surface strategy taxonomy and linguistic category taxonomy errors. The data were collected from recount texts produced by 19 students who were known to make errors in writing. The data was analyzed by calculating the percentage of errors based on the total cumulative errors for surface strategy taxonomy, but based on the number of attempts in the same grammatical elements for linguistic category taxonomy. The results of data analysis showed that the dominant errors for surface strategy taxonomy were selection $(72 \%)$ followed by omission (14.4\%), and addition (10.6\%). In the linguistic category taxonomy, the most dominant types were word forms $(48.4 \%)$, followed by articles (35\%), nonfinite verbs (34.9\%), verb tenses $(34.3 \%)$, plurals $(33.3 \%)$, and prepositions $(30 \%)$. It is suggested that teachers pay more serious attention to the most serious problems because solving these problems will hasten the students' progress in learning.

Keywords: most serious errors; surface strategy taxonomy; linguistic category taxonomy 


\section{Errors in EFL writing by junior high students in Indonesia}

\section{Introduction}

In Indonesia, English is taught as a foreign language starting from high school to university. Most high schools offer two classes of English a week every semester throughout the two levels of high schools, i.e. junior and senior high schools, which take three years for each. For undergraduate university level, only two credits are offered. Some universities only offer English in one semester, but others offer it in two or more. Even different study programs at the same university vary in the number of English modules they offer. However, despite being taught English for more than six years, students in Indonesia have not shown satisfactory English ability after they graduate. At Syiah Kuala University, the first and biggest state university in Aceh Province, students need to show their level of English proficiency as a requirement for graduation, i.e. they need a minimum PBT-TOEFL score (without TWE) of 450. The data from the Language Center of Syiah Kuala University revealed that, in 2015 , of 6,812 students taking the test, only 24 percent of them obtained 450 or more.

In the Indonesian high school curriculum, writing is one of the skills taught in the English module and Hussain, Hanif, Asif, and Rehman (2013, p. 831) claimed that it is the most complicated skill because it requires much concentration, conscious efforts and practice in all its steps, i.e. composing, developing and finalising. Until finishing the final draft, many intensive revisions are usually required. Therefore, it is not surprising that students mostly commit errors in this skill; however, making errors are helpful in learning according to Raimes (1983, p. 3), as long as they are informed about the errors and taught how to correct them.

The most frequent errors made by students are verb tenses and prepositions (Kırkgöz, 2010, p. 4354). In addition, James (1998, p. 486) writes that lexical errors are another most commonly found error in EFL student writing. These errors can be caused by carelessness, L1 and L2 interference, over-generalisation, over-simplification, misunderstanding of rules, and partial knowledge of certain rules (Saeed, Hussain, \& Fatima, 2015 , p. 121), but mostly they are due to lack of practice. Due to errors which are always committed by second and foreign language learners, error analysis has become popular in assessing the standard of language produced by second and foreign language learners. Zawahreh (2012, p. 281) considered error analysis as "the best type of linguistic study that focuses on the errors made by learners". These errors can be analysed whether from an essay or a short writing exam.

In the Indonesian curriculum, junior high school students are expected to be able to write in many varied text genres, i.e. description, recount, spoof, anecdote, procedure, narrative, explanation, discussion, commentary, news, report and review. As a result, students in Indonesia are producing many errors in their compositions because each genre of text has its own unique language features. In fact, a study by Megaiab (2014, p. 190) revealed that from 140 compositions by students, 1654 grammatical errors were found in spelling, plurals, verb tenses, prepositions, articles, capitalisation and punctuation. What most teachers do to solve the problems of their students was to apply a method or technique which addressed the problems of the students in general (Miftah, 2010; Sa'diyah, 2011; Siti Utami, Rais, \& Setyaningsih, 2012). Each problem that the students have correlates from one to another and the most common problems influence other problems to a greater extent compared to less frequent ones. Therefore, it is necessary to solve the common writing problems of students from the most frequent errors to the least ones, as suggested by some experts i.e. "teacher could help students by focusing on areas that seemed most troublesome" (Kim, 2008, p. 280). Therefore, this research was intended to find out what are the most common errors made by students at one of the junior high schools in Banda Aceh, Indonesia, as a sample of writing problems in secondary schools in Indonesia. A few works conducted previously have tried to show these errors. However, they analysed the percentage of errors by calculating one type of error based on the cumulative totals of all types of errors. This way of calculating the percentage of errors does not show which language features are most problematic. The students commit more errors of, for example, verb tenses simply 
because every sentence requires knowledge of verb tenses, but not every sentence requires knowledge of other language features, making them less common compared to the verb tenses. Therefore, the current research analysed the percentage of errors based on the number of attempts in that one particular type of error, instead of the total errors for all types. The results will show the real rank of errors in terms of seriousness produced by students in writing.

\section{Literature Review}

In this section the concept of error analysis, procedures for conducting error analysis, types of errors and the cause of errors are discussed, in addition to steps in writing.

\subsection{Error analysis}

Producing errors can be perceived as a normal part of learning anything especially something as complex as a language, particularly, a foreign language. It is natural that the learners make some errors in their language learning process (Nunan \& Lamb, 1996, p. 68; Boroomand \& Abusaeedi, 2013, p. 80). Processes to analyse those errors are called error analysis. They are processes of analysing errors produced by learners who learn a second language or foreign language using some procedures in order to find the mistakes or misuses. James $(1998$, p. 1) extended the definition of error analysis to cover not only the process of finding the errors but also to determine their causes and consequences. There are four steps in error analysis proposed by Corder (1991, pp. 14-17), Ellis (1997, pp. 15-21), and Vásquez \& Alberto (2008, p. 136), i.e. (i) identifying, (ii) describing, (iii) explaining and (iv) evaluating.

In identifying errors, the sentences written by EFL/ESL students are compared with possible correct/ grammatical sentences. Sentences or parts of sentences which showed contrast in terms of linguistic to those normally used in the target language should be considered to have errors, or at least be candidates for errors. In this step, we need to make sure that the one noted as an error is indeed an error. In our context it is considered an error when a student commits it more than once. Otherwise, it is called a mistake which can occur when hurried, distracted, tired or their concentration is disturbed.

When all the errors in a composition have been identified, they can then be classified into types of errors. Vásquez and Alberto (2008, p. 137) state that errors can be classified into two descriptive taxonomies, i.e. "linguistic category and surface strategy". In linguistic category taxonomy, errors are classified into grammatical categories such as verbs, adjectives, nouns, comparison, etc. Meanwhile, in surface strategy taxonomy, errors are classified into more general categories which include omission, e.g. I going, addition, e.g. I can to go, misformation, e.g. It was readed, and misordering, e.g. I go usually to school at 6 (Ellis, 1997, p. 18; Vásquez \& Alberto, 2008, p. 138).

After classifying errors, how the errors occurred needs to be explained. There are two possible explanations for how errors are produced by EFL learners according to Vásquez and Alberto (2008, p. 138). The first is errors are caused by first language interference, which Richards (1971, p. 205) referred as "interlingual errors". These errors occur when a learner tries to directly translate a sentence or part of a sentence into the target language without considering how a native speaker of the language would normally write it. The other explanation causes errors known as "intralingual errors" (Gass \& Selinker, 2008, p. 103). These are errors caused by lack of knowledge regarding the target language rules which includes "faulty generalisation, incomplete application of rules, and failure to learn conditions under which rules apply” (Richards, 1971, p. 206).

The last step in error analysis is to evaluate errors. Ellis (1997, p. 20) considered that evaluating errors is essential if the error analysis is intended to identify students' problems so that teachers can help solve them. Some errors are not as serious a problem as others. Vásquez and Alberto (2008, p. 140) and Ellis (1997, p. 19) have claimed that there are global errors and local errors. Touchie (1986, p. 76) pointed out that local errors are not very problematic because they do not change the meaning and the writer can still be understood despite the 
errors. Meanwhile, he added that global errors hinder the communication because they change the meaning of what the writer is trying to express or they are difficult to understand. Therefore, teachers should consider focusing on global errors before local errors, as suggested by Ellis (1997, p. 19).

\subsection{Writing}

The best way to analyse errors produced by a language learner is by assessing their writing or speaking because those skills are productive skills in which the learners produce language with errors. However, the focus of this paper is only on writing. This is the ability of arranging ideas and/or information into sentences or paragraphs and making efforts to connect ideas cohesively and coherently from one paragraph to another by following rules of language. The arrangement is based on the general structure of the genre of a text. Therefore, expressing ideas or thoughts is not the only way to create good writing but the ideas should also be covered in acceptable written language so that they are meaningful. In general, the purposes of writing are "to inform, to persuade, to express, or to entertain" (Dietsch, 2003, p. 10). In teaching a language, in addition to the above purposes, writing is also intended to help learners in learning because it enhances grammar skills and lexical skills, and also provides opportunities to produce language in addition to speaking skills (Harmer, 2004, p. 33).

Producing good writing is a challenging task for all language learners and even for native speakers of the language. Grenville (2001, pp. 9-165) proposes six processes of writing which can be used for any kind of writing, i.e. getting ideas or information, choosing ideas or information, outlining, drafting, revising and editing. The activity of getting ideas or information can be done using brainstorming techniques such as listing, mind mapping or free writing (Chin, Koizumi, Reid, Wray, \& Yamazaki, 2012, pp. 5-7). Listing is an activity where all ideas are listed without rejecting any of them, even crazy ones, because they might turn out to be useful later on. Mind mapping is an activity where an idea or concept is linked to related information by drawing lines. Finally, free writing is an activity of writing down all thoughts continuously without worrying about organisation or grammar. After all the ideas are written down, the list will contain scrambled words, phrases, and sentences which will confuse students if they are to make a composition based on the list. Therefore, related ideas are selected and the others, which definitely cannot be used, are eliminated. For that purpose, Grenville (2001, p. 49) suggests what should be considered to make this activity easy, i.e. to keep in mind about in what area this writing will be used and what is the purpose of this writing. Based on this framework, only ideas related to the area and purpose of the writing are kept, making the list tidier.

When the list becomes clean and neat, the students are ready to outline the areas on the list. In outlining, the students arrange all ideas chosen into an in-order list. Therefore, all they need to do next is only to keep their writing going without worrying about the structure but just concentrate on getting each sentence written (Grenville, 2001, p. 70). There are basic kinds of order needed by a writer to concern before outlining i.e. $a$ beginning which contains the introduction of a topic and its setting, a middle which contains the main content of writing, last is an end which gives the last information needed (Grenville, 2001, p. 70). In more detail, the outline should follow the genre of the writing because each genre has its own specific generic structure.

After the students are ready with the outline, they can proceed to the stage where they firstly try to develop the ideas chosen into longer sentences. This stage is well-known as the drafting stage. As it is going to produce a draft of the writing, the writers should not be worried about making mistakes and producing errors because the aim of drafting is to develop and connect each idea obtained from brainstorming and idea selection. It is "all about being pulled into your topic and letting it carry you along right behind" (Peha, 2002, p. 3). Teachers should not score the writing drafts of the students, nor should they be used as the final stage of the writing process (Grenville, 2001, p. 105).

The first draft produced by the students needs to be revised, so the draft needs to be assessed by the students themselves or by others such as classmates or teachers. This activity includes cutting, adding or moving parts of the draft if required (Grenville, 2001, p. 137). According to Peha (2002, p. 5), this stage is very difficult for the 
writers because it involves making clear their ideas and ensuring that each sentence belongs where it is written. As much as the students find it challenging, it is a very essential process because, according to Hedge (2005, p. 121), it gives the students feedback right after they finish the writing, which will help them write a better draft in the future.

After the students receive feedback from the revision process, the last stage of producing good writing is editing where the students make changes and corrections according to the feedback. In addition to revising the draft with respect to coherence and cohesion, Hogue (1996, pp. 16-17) and Grenville (2001, p. 167) proposed some other steps in revising a writing draft, which include revising grammar, punctuation and spelling, and paraphrasing. However, Harmer (2004, p. 5) argued that a more advanced language user tends to look at general ideas before focusing on specific elements suggested by Hogue (1996, pp. 16-17) and Grenville (2001, p. 167) above. After the editing process, the writing is expected to be error free, so readers can easily understand every point the writers make.

\subsection{Types of errors in writing}

Writing comprises three elements as proposed by Watcharapunyawong and Usaha (2013, p. 69), i.e. organisation, content, and linguistic. If students commit errors in writing, the errors should be in these three elements of writing. However, this paper only deals with linguistic errors because Weigle (2002, p. 35) classified these errors into ones needing more attention. Linguistically, errors can be classified into grammatical categories such as errors in tenses, articles, word forms, etc. In more general classification, Brown (2007, p. 262), Corder (1991, p. 36-37), and Ellis (1997, p. 18) identified four categories of linguistic errors, i.e. omission, addition, selection, and misordering.

Omission is some necessary part of words, morphemes, or auxiliaries that may be left out by the learner because of his ignorance as to how to produce correct words. In one well-known recent experiment, Dulay, Burt, and Krashen (1982) found that verification that grammatical morphemes, such as verbs, articles, nouns, prepositions, inflections, are left out more often than the content of morphemes which carries the meaning. As an illustration, in the sentence "coconut basic ingredient many curries" the grammatical morphemes is, a and for are left out.

Addition is the adding of some unnecessary or redundant parts of words, for instance, using both modal and verb be or adding $-s$ to nouns which are similar in forms for both singular and plural forms, or uncountable nouns. The presence of these extra items has been divided into three categories by Dulay et al. (1982), the first one is double marking, as in "did you needed help?", and regularisation, e.g. "mousses, spreaded, criterias, etc". The last is simple addition which includes the rest of the additions.

Selection, also known as misformation (Dulay, Burt, \& Krashen, 1982, p. 158), is choosing wrong word forms. For example, "Aisya is smartest than Boby", instead of "Aisya is smarter than Boby". The wrong word selection usually occurs in the selection of phoneme, morpheme, structure or vocabulary items. It happens when one word is substituted with another similar word.

Finally, misordering is an incorrect order of words in a sentence. As an illustration, "do not leave in the rain her waiting outside" where in the rain is incorrectly placed. Erdogan (2005, p. 264) gave some examples of misordering; in morphology e.g. "get upping" for "getting up", in syntax e.g. "he is a dear to me friend" instead of "he is a dear friend to me", and lastly in lexicon e.g. "key car" for "car key". The latter is often done by Indonesians transferring or literally translating from Bahasa Indonesia.

\section{Methods}

To collect the data for this research, the writer gave a writing test to 19 students studying in the second year at a middle school in Banda Aceh, SMP N 7 Banda Aceh. The students in the second year are about fourteen 
years of age. There were seven classes in the second year, two of which were high-achieving and two were low-achieving classes. Participants who were known to regularly commit errors were selected from both class levels. They were instructed to write a recount essay about their own unforgettable experience with a minimum of 150 words in 60 minutes. The recount text format was used in this research because the participants selected had learned this text genre in previous class meetings at the school.

After collecting the essays, the writer analysed the errors found in the essays by using the steps in error analysis discussed in the previous section, i.e. identifying, describing, explaining and evaluating errors. After categorising all the errors, the writer analysed the distribution of errors found in the essays. The data was then organised into tables to show the frequency and percentage of each type of error. After all the data showed the frequency of errors and the occurrences, the researcher started describing the data.

The errors found in writing were presented in two categories, i.e. surface strategy taxonomy errors and linguistic category taxonomy errors. For surface strategy taxonomy errors, the percentage of errors was calculated based on the cumulative totals of errors in each subcategory under the taxonomy. However, for the linguistic category of errors, the percentage of errors was calculated based on the number of attempts in that one particular sub-category, instead of the total errors for all subcategories. For example, a group of students committed 2000 errors all together. They tried to use prepositions 100 times but only 50 of them were correctly selected or omitted or unnecessary added; therefore, the percentage of errors in using prepositions was $50 \%$. This method of analysing data was aimed at avoiding misleading interpretations of the information. Thus, we cannot conclude that students did not have any problem with preposition if they only attempted to use prepositions three times, or did not attempt to use any preposition at all, or the sentences that the students wrote did not require any prepositions.

\section{Findings and Discussion}

The analysis of errors found a total of 368 words and phrases containing errors. Of all these errors, mis-selection was the most common type of error found in the students' essays according to the surface strategy taxonomy of errors. This was followed by omission and addition, whilst misordering was found the least.

\section{Table 1}

Number of errors based on surface strategy taxonomy of errors

\begin{tabular}{lccc}
\hline & Type of Error & Number of Errors & Percentage of Occurrence \\
\hline Mis-selection & & 259 & $70 \%$ \\
Omission & 53 & $14 \%$ \\
Addition & & 39 & $11 \%$ \\
Misordering & & 17 & $5 \%$ \\
& & 368 & $100 \%$ \\
\hline
\end{tabular}

The most common type of error in the surface strategy taxonomy found in this study was mis-selection. They were usually concerned with the rules of word formation which are abundant in English, and thus require a lot of effort to learn. Below are some examples of mis-selection errors produced by the students:

Last weekend, I gone to a restaurant...

We went there for get fresh air but the weather.........

I must passed through a narrow slippery street.

In the first example, the student intended to write his/her past story. Therefore, it is clear that the verb go in this sentence must be in the past form went, not the past participle gone. In the second example, the students used the preposition for instead of the infinitive marker to. In the third example, the verb following an auxiliary should be in base form, i.e. pass in this example. However, the student selected an incorrect form, i.e. the past 
form passed.

Omissions were the second most common type of error in the surface strategy taxonomy of errors committed by the students in their recount essays. Errors in omissions are made when essential elements such as primary verbs, articles, prepositions, punctuations are omitted. Examples of omission errors produced by the students follow:

*All my friends not care to me.

*... but after promise assemble at $2.15 \mathrm{pm}$

*I was holiday the beach.

In the first example, a required word was omitted in the sentence, i.e. auxiliary verb did, which is a primary requirement for a negative sentence in English. In the second example, the subject of the sentence was left out. The subject was present in the previous sentence, hence the student considered that it was not necessary to state it in this sentence or it could be rewritten as an adjectival phrase. Also, an infinitive marker to was omitted.

In the third example, omission of a preposition shows lack of knowledge regarding prepositional phrases. In addition, the nonfinite verb having and indefinite article $a$ were also absent in the third example. It seems that the student used holiday as a lexical verb in the sentence instead of using holidaying. The sentence could be corrected into I was having a holiday at the beach or I was holidaying at the beach.

In addition to omitting required parts of a sentence, some students added unnecessary words or phrases which made their sentences wrong. This is the third most common type of error in terms of surface strategy taxonomy of errors. Some examples follow:

*He was tried to hit us.

*Whereas, that day's is my birthday.

*I see something the little and the black....

In the first example, the verb be was unnecessarily added to a past passive sentence. In the second example the short form of be ('s) was used before using the verb be, producing redundancy in terms of syntax. The third example unnecessarily used the article the before the adjectives little and black. Although the definite article the can be used before an adjective to indicate a noun, in the context above the words little and black were semantically adjectives.

The least common type of error found in the essays was misordering. Only 17 of these errors were found amongst the 368 errors (5\%). It suggests that only a few students had problems with this type of surface strategy taxonomy error. Some of these errors are as follows:

*My teacher is name Armasih, Eni, Marziah.

*... at the port Ulhee-lheu.

In the first example, the finite verb be which should precede the "teacher's name" was inserted into the subject. Finally, in the second example, the adjective-like modifier was used after the noun instead of before the noun it modifies.

Thus, second year students at a middle school in Indonesia, learning English as a foreign language, made all four types of error in the surface strategy taxonomy of errors. The most common errors were mis-selections, followed by omissions and additions. This suggests that the learners have already passed the early stage of English language learning. Dulay et al. (1982, p. 162) stated that errors in (mis)selection "indicate that some 
learning has transpired". In addition, omissions were only common with students learning at an early stage (Dulay et al., 1982, p. 155). Meanwhile, omissions were found to be not very common (only 14.40\%) in the current research, which confirms that the students were no longer in their early stage of learning. In addition, errors in addition include omissions of auxiliaries be and do, as in All my friend not care to me, which according to Dulay et al. (1982, p. 121) indicates that the progress of learning has been made. For additions, it is not unexpected to find small percentage of errors in this category because it is less likely that students are able to overuse words as they have been claimed to lack vocabulary and limited knowledge of grammar. Of all errors in the surface strategy taxonomy, misorderings are the least common type of error. The fact that misordering errors were the least common type of error confirms previous claim that the students were not complete beginners because this type of errors was only produced by low achieving learners who rely very much on their L1. This is supported by Gass and Selinker (2008, p. 151) who wrote "beginning learners rely on their L1 processing strategies"

The analysis of errors in the surface strategy taxonomy of errors indicated the level of English proficiency of the students. However, this categorisation does not provide teachers with meaningful information to predict their real learning difficulties (Corder, 1991, p. 36). Corder, (ibid), believed that explaining errors from the linguistic category is more beneficial. Instead of saying that the students made an error of selection, it is more useful if a teacher is told that his students still have difficulties in deciding what verb form to use in a passive sentence. Therefore, this paper also explains errors based on linguistic category taxonomy. Table 2 below summarises the errors found in the essays based on linguistic category taxonomy.

\section{Table 2}

Number of errors based on linguistic category taxonomy

\begin{tabular}{|c|c|c|c|c|}
\hline Types of Errors & Number of Attempts & Number of Errors & $\begin{array}{c}\text { Percentage of errors } \\
\text { based on number of } \\
\text { attempts }\end{array}$ & $\begin{array}{l}\text { Percentage of errors } \\
\text { based on total errors }\end{array}$ \\
\hline Word form & 124 & 60 & 48 & 16 \\
\hline Article & 100 & 35 & 35 & 10 \\
\hline Non-finite verb error & 43 & 15 & 35 & 4 \\
\hline Verb Tense & 277 & 95 & 34 & 26 \\
\hline Plurality & 51 & 17 & 33 & 5 \\
\hline Preposition & 152 & 45 & 30 & 12 \\
\hline Conjunction & 65 & 14 & 22 & 4 \\
\hline Unnecessary to be & 81 & 16 & 20 & 4 \\
\hline Word Order & 88 & 17 & 19 & 5 \\
\hline S-V Agreement & 129 & 13 & 10 & 4 \\
\hline Primary Verb Missing & 287 & 24 & 8 & 7 \\
\hline Subject Missing & 287 & 13 & 5 & 4 \\
\hline Unnecessary Passive & 5 & 4 & 80 & 1 \\
\hline Total & 1689 & 368 & 22 & 100 \\
\hline
\end{tabular}

Looking through linguistic taxonomy, and by comparing the number of errors to the number of attempts, of 1689 attempts altogether, $368(21.79 \%)$ were erroneous. The most common errors were errors in word forms, followed by articles, nonfinite verbs, verb tenses, plurality, and prepositions, whilst the others are less than $25 \%$ of the attempts. The least common errors were omissions of primary verbs and subjects. Unnecessary passives are ignored in this research because students did not really attempt to produce passive sentences. These results show that EFL students in Indonesia had problems in many grammatical categories. The figures presented in Table 2 are contrast to the research findings of Ridha (2012), Olsen (1999), Watcharapunyawong and Usaha (2013), Moqimipour and Shahrokhi (2015), Lasaten (2014), Kırkgöz (2010), Hussain, Hanif, Asif, and Rehman (2013), and Darus and Subramaniam (2009) who discovered that the most common errors were verb tenses. In fact, the current research revealed that the most frequently misused language features are indeed verb tenses. Therefore, if the number of errors in verb tenses is compared to the total errors in all grammatical categories, as in most researches on error analysis, errors in verb tenses will obviously appear to be the most dominant errors, 
i.e. $25.82 \%$. However, this way of calculating the percentage of errors does not show which language features are most problematic. The students commit more errors in verb tenses simply because every sentence requires knowledge of verb tenses, but not every sentence requires knowledge about articles and other-word forms, making them less common compared to the verb tenses.

The table above shows that word forms are the most troublesome for the students in this research. The errors in word forms include using wrong parts of speech such as using adjective forms when adverbs were required. Many words in English come with many forms such as fright which has 7 forms, i.e. fright, frighten, frightened, frightening, frighteningly, frightful, frightfully, and frightfulness. Derivation in English has been known to confuse English language learners. When students lack vocabulary or knowledge of morphology, students tend to rely on a dictionary. This is evident from one of the sentences found in one of the essays below:

*I am so fright each I see something....

In Bahasa Indonesia, an adjective meaning frightened is "takut". The circumfix ke...an, which gives two possible meanings, one is a feeling of fear and the other is extremely frightened, can be attached to the word takut. However, what most Bahasa Indonesia - English dictionaries define "ketakutan" is as the former, i.e. a feeling of fear. That explains how the students came up with the word fright in the above example. Although L1 transfers contributed to errors in word forms, the most dominant cause of these errors was intra-lingual error. Students commit errors in word forms when they have not completely learnt parts of speech, sentence components, and word formation or derivation. In order that a student is able to use an adverb in a sentence, he or she has to learn the function of adverbs, which is included in the knowledge of parts of speech. Many students have been found to use a noun when a verb is required, which was a result of lack of knowledge about sentence components. In addition, since many word categories derive from other word categories (e.g. knowledgeable from knowledge), a knowledge of how words are formed is essential. Some previous studies have highlighted the fact that students often commit errors in word form (Kafipour \& Khojasteh, 2012; Saad \& Sawalmeh, 2014); however, those researches did not list those errors as the most common errors, perhaps due to a different method of calculation.

Articles are the second most problematic English feature for Indonesian students. Students committed all types of article errors, i.e. adding an article when it was not necessary, omitting an article when it was required, and using a definite article when an indefinite one should have been used and vice versa. Article errors become dominant because in fact articles in students' L1 are indeed not even close in complication compared to those in English. There are many rules a student should learn to be able to use articles correctly in English. In Grammar Way 3 by Dooley and Evans (1999), 37 rules of articles are listed. A TOEFL Preparation book written by Gear and Gear (1996) showed that there are 20 rules for articles. Each book presented exceptions for the rules. These abundant rules to remember, along with their exceptions, confirm that intra-lingual errors must have taken place when students commit errors in articles because it is expected that learning so many rules takes a lot of time and practice. It is also supported by the fact that L1 language learners, who do not have any other language to transfer from, have been found to commit many errors in articles (Dulay et al., 1982, p. 165). Previous research also confirms that articles created problems for Indonesian senior high school students in Bali. In addition, other researchers have found that articles were one of the most problematic structural elements for EFL learners in Arab (Hourani, 2008), Finland (Olsen, 1999, p. 193), Thailand (Watcharapunyawong \& Usaha, 2013), Iran (Moqimipour \& Shahrokhi, 2015), the Philippines (Lasaten, 2014), Jordan (Zawahreh, 2012), Turkey (Kırkgöz, 2010), and Malaysia (Darus \& Subramaniam., 2009). This shows that errors in articles are a universal problem for EFL students.

Other predominant errors are mis-selection of word forms in non-finite verbs. Although this type of error could have been included under the word form errors, they were analysed separately in the current research to show how serious this problem is. The nonfinite verb is "a verb form which is not inflected for tense" (Kroeger, 2005, p. 437). However, most students committing errors of this type marked tense for non-finite verbs such as 
in *My mother allowed us to rode them and *I must passed through a narrow slippery street. Students did not produce other types of nonfinite verb errors such as gerund, infinitive, or addition of inflection -s/es for sentences with singular subjects. Thus, it is clear that the errors are intra-lingual errors. Since the majority of non-finite verb errors were misused past markers, it can be concluded that these errors are caused by incomplete knowledge on how to construct sentences using the past tense. Such problems were also revealed by Hasan (2013), i.e. $61 \%$ of errors in non-finite verbs were found in writing produced by Iraqi third year college students in the Department of English at Tikrit University. Non-finite verb errors were also committed by Chinese EFL learners (Zhan, 2015). However, those previous studies did not show what type of non-finite verb errors was dominant.

In addition, tenses have been known to post unending problems for Indonesian students since Bahasa Indonesia, as well as other local languages in Indonesia, does not have such time marking. Therefore, students need to master new rules in order to avoid such errors. This finding also calls to mind a previous study undertaken by Yahya, Ishak, Zainal, Faghat, and Yahaya (2012) to examine errors made by Malaysian students in written essays at the University of Technology Malaysia. He found that the type of error that most frequently occurred was verb tenses. Not only did those researchers show that verb tenses were the most common problem for EFL learners, a study conducted by Hourani (2008) also showed that the use of English verbs was a major learning difficulty for all Arabian students whose errors in verbs were nearly $21 \%$ of their total errors in essays written by secondary school students from the United Arab Emirates. For pre-intermediate learners, who no longer depend on literal translation, the errors are intra-lingual. In the case of beginners, this type of error is an inter-lingual error, although most errors in tenses found in this research were intra-lingual. The interference of their $\mathrm{L} 1$ is explained in the following example taken from a sample of their writing produced by a beginner level student "*It is my experience of I cannot I am forget" which conveys the influence of the L1 Bahasa Indonesia over English as one can see in the Indonesian version i.e.

Ini adalah pengalaman saya yang saya tidak dapat saya lupakan.

Which back-translated reads:

*It is experience my that I not can I forget.

But in good English would be:

'It was my unforgettable experience'

From the example above, many errors seem to have been caused by literal translation. The sentences showed that the student tried to get his message across by translating his L1 word for word to the target language (Norrish, 1992, p. 26). Unfortunately, this causes confusion for the reader because of the different rules for the two languages.

Plurality is another common error found in the current research, since it scored higher than $30 \%$. Plurality in this research was only limited to the number of wrong plural nouns. There were some singular nouns which should be pluralised, but they are excluded because compared to the number of correctly-used singular nouns, the percentage of incorrect ones was extremely small. Although pluralisation errors seem to be a case of inter-lingual error because nouns in L1 do not inflect for plurality, some researches suggests otherwise. A Hispanic child has been reported to omit plural markers when speaking English while did not do so when speaking his L1 (Dulay et al., 1982, p. 122). Therefore, in this case, the errors are considered as intra-lingual. The major cause of these errors was incomplete knowledge on countability. Half of the uncountable nouns were found in plural form, e.g. *coconut drinks and *ice creams, and nouns such as currency, as well as nouns preceded by quantifiers, were found in singular forms, e.g. *many interior injury, *some pizza, and *100 rupiah. It seems that in addition to countability, students were confused with quantifiers. The results of this research showed us that plurality errors are more serious than we were taught they were. With a different method of analysis, errors in plurality were considered less dominant, such as only $6 \%$ found in research by Zhan (2015) 
Errors in EFL writing by junior high students in Indonesia

and by Watcharapunyawong and Usaha (2013), 9\% by Hourani (2008), 16\% by Moqimipour and Shahrokhi (2015), $1.01 \%$ by Lasaten (2014), $14 \%$ by Kırkgöz (2010), and $13.3 \%$ by Darus and Subramaniam (2009). However, in the current research, of 51 plural nouns found in the essays, 17 of them (33\%) should have been in singular form.

Errors in preposition were also dominant in the essays. Most of the errors were wrong-selection of prepositions as in We took a taxi for the hotel. Some students also omitted prepositions. Since there are many prepositions in English, these errors are due to incomplete learning of the rules. It takes time for the students to learn the usage of the large number of prepositions. In terms of communication, these errors do not hinder communication much; therefore, it is not as serious a problem as other errors. Sometimes, errors in preposition can be regarded as lexical errors since the errors affect meaning and hence students will correct those errors by the time they have an adequate vocabulary. Errors in prepositions were also found in small numbers in previous studies such as 9\% in Darus and Subramaniam (2009), 7\% in Lasaten (2014), and 5.5\% in Lunsford and Lunsford (2008).

The total of all other errors was less than $25 \%$. These errors included conjunctions, unnecessary to be, word order, subject and verb agreement, primary verb missing, and subject missing. Students were found to wrongly select and omit conjunctions. Some sentences were found separated only by a comma, and some were not separated at all. A small number of students overused the verb to be as in I am go. They had misunderstood the concept of a sentence, thinking that the verb to be is required in more types of sentences than it actually is. Errors in subject and verb agreement, primary verb missing and subject missing found in the current research were very small in number.

In short, from six most serious errors produced by junior high students in Indonesia, five of them were inter-lingual, i.e. articles, tenses, non-finite verbs, and plurality. In the students' L1, i.e. Bahasa Indonesia, verbs do not inflect either for tense or agreement, and nouns do not inflect for plurality. Moreover, article rules in Bahasa Indonesia are too simple compared to those of English. Therefore, it is the complexity of grammatical rules in English or incomplete learning of the rules which motivate these errors. It is supported by previous studies conducted in Sri Lanka, India (Abeywickrama, 2010), and Philippines (Lasaten, 2014). Those studies show that L1 negative transfer contributes only little to grammatical errors produced in writing English, which is also supported by Dulay $(1982$, p. 122) in a statement that "many of the errors ... bore no relation to their native language". Researches on errors produced by learners with different L1 gave somewhat the same results, although not in similar order of severity. However, for EFL learners with non-alphabetic system L1, in addition to errors found in the current research, errors in spelling seem to be more frequent, such as EFL learners from China (Huang, 1987, p. 49; Zhan, 2015, p. 74) and Iran (Nezami, Najafi, \& Sadraie Najafi, 2012, p. 166). The errors are obviously caused by students' unfamiliarity to English orthography because, according to Sipra (2013, p. 122), learning English spelling requires a serious endeavor even for L1 children. It is evident from the fact that they often fail Spelling Bee, partly because alphabets in English often do not correspond to sounds, a case which would not likely to happen to Indonesian children if there were Spelling Bee in Bahasa Indonesia.

\section{Conclusions and Implications}

Since making errors is a part of the learning process, it is not unexpected that students make errors at this stage of learning. Teachers can benefit from knowing what errors are more often made by students in order that they can take necessary measures to help their students learn better, faster, and more efficiently. Eliminating all errors cannot be done by clapping hands. Teachers have to focus on teaching how to not make the more common errors before focusing on other errors. Therefore, they have to be provided with results from studies on what types of errors are likely to be the most common. This research studied types of common errors based on two categorisations, i.e. surface strategy taxonomy errors and linguistic category taxonomy errors. Based on surface strategy taxonomy, the most common errors were in word selection. Students mostly committed errors by mis-selecting forms of words although correct base forms were used. The more helpful and informative 
categorisation was the linguistic category taxonomy, which revealed that almost all observed grammatical elements hid problems for students. The most common ones were word forms followed by articles, non-finite verbs, verb tenses, plurality, and prepositions. These results contrast to those in previous studies due to a different way of analysis. The major contrasts are in two different grammatical elements, i.e. verb tenses and plurality. If the number of errors was compared to the number of total cumulative errors, as in most previous studies, verb tenses would appear as the most dominant. However, this does not show the real problems faced by the students. The dominance in errors of verb tenses was because every sentence that a student produces contains a verb; therefore, students must have attempted to produce more verb tenses, giving them more opportunity to commit errors in this grammatical element compared to others. In the current research, the number of errors was compared to the number of attempts for the same grammatical element, which resulted in word form errors to be the most common errors. In addition, errors in plurality were rarely found in students writing (1 to $14 \%)$ according to previous researches; however, the current research showed that the percentage of errors in this element was very high, i.e. $33 \%$.

What has been concluded from the results of this research provided several implications for EFL teachers and learners alike. The study has shown that making errors was unavoidable for EFL learners, either inter-lingual and intra-lingual. The most problematic grammatical errors for students were word forms, followed by articles, non-finite verbs, tenses, and preposition; therefore, EFL teachers can prioritize the teaching and learning process based on that order of errors to encourage students to increase their self-confidence. Another implication is that this problem can be solved by making students able to self-correct the errors, so teachers should train students to self-correct by applying teaching techniques which involve peer review, which will make them more aware of the errors. In addition, having learned that it is those rules of English that are troublesome, students should make themselves familiar with those rules by learning and practicing rules of English grammar in the given order. Researchers should also be benefited from the results of the current study. Now that errors in EFL writing have been revealed, classroom action researches should test teaching methods and techniques which can presumably minimize the errors such as peer review, techniques of providing feedbacks for errors, grammar drills, or self-study like keeping a journal. Other researches using the same method of analysis as this study are to be hoped for, with learners at other levels of proficiency, such as college students majoring in English language teaching or literature, so that EFL teachers can work on solving errors in advanced learners' writing.

\section{References}

Abeywickrama, R. (2010). An analysis of errors in English writing of Sinhala speaking undergraduates. Sabaragamuwa University Journal, 9(1), 97-114.

Boroomand, F., \& Rostami, A. A. (2013). A gender-based analysis of Iranian EFL learners' types of written errors. International Journal of Research Studies in Language Learning, 2(5), 79-92. http://dx.doi.org/10.5861/ijrsll.2013.287

Chin, P., Koizumi, Y., Reid, S., Wray, S., \& Yamazaki, Y. (2012). Academic writing skills student's book 1. Cambridge: Cambridge University Press.

Corder, S. P. (1991). Error analysis and interlanguage. Oxford: Oxford University Press.

Darus, S., \& Subramaniam, K. (2009). Errors in the written English essays of secondary school students in Malaysia: A case study. European Journal of Social Sciences, 8(3), 483-495.

Dietsch, B. M. (2003). Reasoning \& writing well: A rhetoric, research guide, reader, and handbook. Ohio: McGraw-Hill.

Dooley, J., \& Evans, V. (1999). Grammarway 3. Berkshire: Express Publishing.

Dulay, H., Burt, M., \& Krashen, S. (1982). Language two. New York: Oxford University Press.

Ellis, R. (1997). Second language acquisition. New York: Oxford University Press.

Erdogan, V. (2005) Contributions of error analysis to foreign language teaching. Mersin University Journal of Education, 1(2), 261-270.

Gass, S. M., \& Selinker, L. (2008). Second language acquisition. New York: Routledge. 
Errors in EFL writing by junior high students in Indonesia

Gear, J., \& Gear, R. (1996). Cambridge preparation for the TOEFL test (2nd ed.). New York: Cambridge University Press.

Grenville, K. (2001). Writing from start to finish: A six-step guide. NSW: Allen \& Unwin.

Harmer, J. (2004). How to teach writing. Essex: Pearson Education Limited.

Hasan, W. M. (2013). Error analysis in nonfinite verbs forms. Journal of Al-Frahids Arts, 17, 527-569.

Hedge, T. (2005). Writing ( $2^{\text {nd }}$ ed.) Oxford: Oxford University Press.

Hogue, A. (1996). First steps in academic writing. New York: Addison Wesley Longman.

Hourani, T. M. Y. (2008). An analysis of the common grammatical errors in the English writing made by $3 r d$ secondary male students in the Eastern Coast of the UAE (Master's Dissertation). Retrieved from http://bspace.buid.ac.ae/handle/1234/225

Huang, J. (1987). Error analysis: A study of errors in Chinese ESL learner writing (Master's Thesis). Retrieved from the Humanities and Social Sciences Collection (Accession No. 303644522).

Hussain, Z., Hanif, M., Asif, S. I., \& Rehman, A. U. (2013). An error analysis of L2 writing at higher secondary level in Multan, Pakistan. Interdisciplinary Journal of Contemporary Research in Business, 4(11), 828-844.

James, C. (1998). Errors in language learning and use: Exploring error analysis. London: Longman.

Kafipour, R., \& Khojasteh, L. (2012). A comparative taxonomy of errors made by Iranian undergraduate learners of English. Canadian Social Science, 8(1), 18-24.

Kim, H. J. (2008). Error analysis. In J. M. González (Ed.), Encyclopedia of bilingual education (Vol. 1, pp. 280-283). Thousand Oaks, CA: SAGE Publications. http://dx.doi.org/10.4135/9781412963985.n112

Kirkgöz, Y. (2010). An analysis of written errors of Turkish adult learners of English. Procedia - Social and Behavioral Sciences, 2(2), 4352-4358. http://dx.doi.org/10.1016/j.sbspro.2010.03.692

Kroeger, P. R. (2005). Analysing syntax: An introduction. New York: Cambridge University Press.

Lasaten, R. C. S. (2014). Analysis of errors in the English writings of teacher education students. Researchers Word Journal of Arts, Science \& Commerce, 5(4), 92-101.

Longman Dictionary of Contemporary English (3rd Ed). (2001). Harlow UK: Pearson Education Ltd.

Lunsford, A. A., \& Lunsford, K. J. (2008). "Mistakes are a fact of life": A national comparative study. The National Council of Teachers of English, 59(4), 781-806.

Megaiab, M. M. A. (2014, May). The English writing competence of the students of an Indonesian senior high school. Paper presented at the WEI International Academic Conference, Bali, Indonesia.

Miftah, M. Z. (2010). Improving the tenth-year students' writing ability at MA Nambaus Sholihin Gresik through mind mapping. LINGUA Jurnal Ilmu Bahasa dan Sastra, 5(2), 178-204.

Moqimipour, K., \& Shahrokhi, M. (2015). The impact of text genre on Iranian intermediate EFL students' writing errors: an error analysis perspective. International Education Studies, 8(3), 122-137. http://dx.doi.org/10.5539/ies.v8n3p122

Nezami, A., Najafi, M. S., \& Sadraie Najafi, M. (2012). Common error types of Iranian learners of English. English Language Teaching, 5(3), 160-170. http://dx.doi.org/10.5539/elt.v5n3p160

Nunan, D., \& Lamb, C. (1996). The self-directed teacher: Managing the learning process. Cambridge: Cambridge University Press.

Olsen, S. (1999). Errors and compensatory strategies: A study of grammar and vocabulary in texts written by Norwegian learners of English. System, 27(2), 191-205. http://dx.doi.org/10.1016/S0346-251X(99)00016-0

Peha, S. (2002). The writing process notebook. Retrieved from http://www.ttms.org/PDFs/ 04\%20Writing\%20 Process\%20v001\%20(Full).pdf

Raimes, A. (1983). Techniques in teaching writing. New York: Oxford University Press.

Richards, J. C. (1971). A Non-contrastive approach to error analysis. ELT Journal, 25(3), 204-219. http://dx.doi.org/10.1093/elt/XXV.3.204

Ridha, N. S. A. (2012). The effect of EFL learners' mother tongue on their writings in English: An error analysis study. Journal of the College of Arts, 60, 22-45.

Sa'diyah, H. (2011). Improving students' ability in writing descriptive texts through a picture series-aided 
Mustafa, F., Kirana, M., \& Bahri Ys, S.

learning strategy. The English Teacher, 40, 164-182.

Saad, M. A. H., \& Sawalmeh, M. H. M. (2014). Error analysis in role-play presentations among less proficient L2 Malaysian learners. International Journal of English and Education, 3(3), 346-355.

Saeed, A., Hussain, S., \& Fatima, S. (2015). Prepositional errors in the writings of Pakistani ESL students. International Journal of English Linguistics, 5(3), 120-128. http://dx.doi.org/10.5539/ijel.v5n3p120

Sipra, M. A. (2013). Impact of English orthography on L2 acquisition. English Language Teaching, 6(3), 116-124.

Siti Utami, F., Rais, D., \& Setyaningsih, E. (2012). Improving students' writing skill using a four-phase technique. English Education, 1(1), 1-14.

Touchie, H. Y. (1986). Second language learning errors: Their types, causes and treatment. JALT Journal, 8(1), 75-80.

Vásquez, L. O., \& Alberto, D. (2008). Error analysis in a written composition. Profile Issues in Teachers` Professional Development, 135-146.

Watcharapunyawong, S., \& Usaha, S. (2013). Thai EFL students' writing errors in different text types: The interference of the first language. English Language Teaching, 6(1), 67-78.

Weigle, S. C. (2002). Assessing writing. Cambridge: Cambridge University Press. http://dx.doi.org/10.1017/CBO9780511732997

Yahya, A., Ishak, H. B., Zainal, Z., Faghat, L. J., \& Yahaya, N. (2012, March). Error analysis of L2 learners' writings, a case study. Paper presented at the International Conference on Language, Medias and Culture, Singapore.

Zawahreh, F. A. S. (2012). Applied error analysis of written production of English essays of tenth grade students in Ajloun Schools, Jordan. International Journal of Learning \& Development, 2(2), 280-299. http://dx.doi.org/10.5296/ijld.v2i2.1680

Zhan, H. (2015). Frequent errors in Chinese EFL learners' topic-based writings. English Language Teaching, 8(7), 72-81. http://dx.doi.org/10.5539/elt.v8n5p72 